\title{
ANALISIS RANTAI NILAI KOMODITI KELAPA (Cocos nucifera $L$.) DI DISTRIK MISOOL UTARA KABUPATEN RAJA AMPAT
}

\author{
Ery Atmodjo ${ }^{*}$, Rajab $^{2}$ \\ ${ }^{1}$ Fakultas Pertanian, Universitas Negeri Papua \\ Jl. Gunung Salju, Amban, Manokwari, Kode Pos. 98314 \\ ${ }^{2}$ Jurusan Peternakan Fakultas Pertanian, Universitas Pattimura \\ Jln. Ir. M. Putuhena, Kampus Poka, Ambon, Kode Pos. 97233 \\ *Email: $\underline{\text { e atmojo@gmail.com }}$
}

\begin{abstract}
ABSTRAK
Selain menggunakan pendekatan kawasan, pengembangan produk unggulan seperti halnya komoditi perkebunan kelapa di Misool Utara perlu juga menerapkan pendekatan rantai nilai. Penelitian ini bertujuan untuk mengetahui rantai nilai dan nilai strategis produk kelapa sebagai komoditas unggulan di Distrik Misool Utara. Teknik pengumpulan data yang utama adalah wawancara semi struktural dilaksanakan secara perorangan maupun kelompok (focus group discussion/FGD). Jenis data yang dikumpulkan dalam kajian ini digolongkan menjadi data primer dan data sekunder. Data primer diperoleh dengan cara wawancara terhadap para pemangku kepentingan dan pengamatan lapangan, sedangkan data sekunder diperoleh dari kajian pustaka terhadap laporan-laporan dan dokumen-dokumen lembaga Pemerintah seperti antara lain BPS, Bappeda, dan OPD terkait. Data yang diperoleh dianalisis dengan metode kualitatif. Hasil penelitian menunjukkan bahwa luas panen perkebunan kelapa rakyat di kawasan Distrik Misool Utara adalah 1646 hektar, produksinya mencapai 805,94 ton dengan rata-rata kontribusi bagi pendapatan keluarga petani sebesar 4,97 juta rupiah per bulan. Rantai nilai kelapa mulai produksi, pengolahan dan pengumpulan kopra tersebar semuanya dijual kepada pedagang kopra antar pulau yang menjual kopra ke Bitung, dan program peningkatan produktifitas dan agribisnis kelapa diperkirakan dapat meningkatkan produksi kelapa sebesar $10 \%$ per tahun.
\end{abstract}

Kata kunci: Rantai nilai, nilai strategis, kelapa (Cocos nucifera L.)

\section{VALUE CHAIN ANALYSIS OF COCONUT (Cocos nucifera L.) COMMODITIES IN NORTH MISOOL DISTRICT RAJA AMPAT REGENCY}

\begin{abstract}
Besides using area approach, pre-eminent product development such as coconut (Cocos nucifera L.) commodities in North Misool also need apply value chain approach. The aim of this research were to know both value chain and the strategic value of coconut product as main agriculture commodity in North Misool. Primary data collecting technique was conducted by means of structural semi interview method for man to man of respondent ar by using focus group discussion. Data type collected in this study was classified to primary and secondary data. Primary data obtained by interview to all of importance respondents and field observation, while secondary data sekunder obtained from literacy study from government agency documents and reports such as BPS, Bappeda, and other relevant references. Data collection was analysed by using the qualitative method. The result of research showed that the rate of the coconut plantation harvest in North Misool was 1,646 hectare, with coconut production reach up to 805.94 tones per year and the mean of its contribution for earnings of farmers was equal to 4.97 million rupiah per month. The value chain of coconut product was started by production, processing and copra gathering gone the round of altogether sold to interisland merchant then selling copra to Bitung. The program to increase both productivity and agribisnis of coconut was estimated can increased coconut product up to $10 \%$ per year.
\end{abstract}

Key words: Value chain, stratetegic value, coconut (Cocos nucifera L.) 


\section{PENDAHULUAN}

Percepatan pembangunan wilayah pedesaan di Kabupaten Raja Ampat Provinsi Papua Barat dilaksanakan melalui metode pendekatan kawasan. Melalui pendekatan ini pembangunan kampungkampung yang berdekatan dilakukan secara sinergis berdasarkan kesamaan agroekologi. Kampungkampung yang berdekatan dalam kawasan dan memiliki kesamaan agroekologi didorong untuk bekerjasama menghasilkan produk unggulan berdasarkan potensi yang ada. Seperti halnya kawasan lain di Kabupaten Raja Ampat, kawasan pulau Misool dan pulau-pulau di sekitarnya serta perairannya mengandung potensi sumber daya alam yang besar, salah satunya untuk pengembangan pertanian secara umum, yaitu pertanian, perkebunan, dan peternakan.

Telaah agroekologi secara lebih rinci memberikan gambaran bahwa dari berbagai komoditas pertanian yang diusahakan oleh petani, kelapa merupakan komoditas unggulan di kawasan Misool. Secara lebih spesiffik kelapa merupakan komoditas unggulan di Kawasan Misool Utara. Kelapa (Cocos nucifera) merupakan komoditas yang memiliki peran sosial, budaya, dan ekonomi dalam kehidupan masyarakat Indonesia. Tanaman kelapa tersebut dikenal oleh masyarakat Indonesia karena seluruh bagiannya dapat dimanfaatkan, sehingga kelapa dijuluki sebagai pohon kehidupan (the tree of life). Penggunaan kelapa sebagai bahan baku pembuatan minyak goreng dimulai pada awal tahun 1960 dan terus mengalami peningkatan hingga pada era tahun 1980. Pada saat itu tanaman kelapa mendominasi lahan di berbagai wilayah di seluruh Indonesia (Basmar, 2008). Namun, usaha tani kelapa di Misool Utara pada belum banyak terkait dengan industri pengolahan, industri hilir, industri jasa, keuangan dan pemasaran. Akibatnya agribisnis kelapa tidak berhasil mendistribusikan nilai tambah secara optimaldan proporsional. Pengelolaan usahatani kelapa masih bersifat tradisional dan terbatasnya modal, maupun kualitas produk yang dihasilkan masih rendah. Sampai sat ini belum banyak berubah sehingga komoditas kelapa yang mempunyai multiguna relatif tidak ada nilai tambahnya (Wardhanu dan Anhar, 2017).

Kawasan Misool Utara diarahkan menjadi pusat produksi dan industri pengolahan kelapa dan hasil perikanan. Kawasan Waigama-Salafen sebagai kawasan prioritas di Misool Utara ditetapkan sebagai pusat pengumpulan dan industri pengolahan kelapa dan perikanan menjadi produk-produk unggulan kawasan. Kampung-kampung lain di Misool Utara menjadi pusat produksi pertanian dan perikanan yang memasok bahan baku bagi pusat industri. Selain menjadi pusat pengumpulan dan industri pengolahan, kawasan Waigama-Salafen juga menjadi pusat pendidikan dan pelatihan bidang pertanian. Kawasan Waigama-Salafen dipilih untuk itu karena memiliki kesiapan infrastruktur dan fasilitas pelayanan sosial ekonomi yang paling baik (Bappeda Kabupaten Raja Ampat, 2007).

Selain menggunakan pendekatan kawasan, pengembangan produk unggulan seperti halnya komoditi perkebunan kelapa di Misool Utara perlu juga menerapkan pendekatan rantai nilai. Keberadaan perkebunan kelapa selama ini masih belum memberikan hasil yang optimal, salah satunya disebabkan oleh belum adanya rantai nilai (value chain) yang dapat memberikan win-win solution kepada semua pelaku usaha (Dahniar dkk., 2016). Rantai nilai adalah suatu metode penilaian dimana bisnis dilihat sebagai rantai aktivitas yang mengubah input menjadi output yang bernilai bagi pelanggan. Nilai bagi pelanggan berasal dari tiga sumber dasar: aktivitas yang membedakan produk, aktivitas yang menurunkan biaya produk, dan aktivitas yang dapat segera memenuhi kebutuhan pelanggan.

Analisis rantai nilai dapat digunakan sebagai alat analisis strategi yang digunakan untuk memahami secara lebih baik terhadap keunggulan kompetitif, dimana produsen atau perusahaan dapat meningkatkan nilai tambah maupun penurunan biaya sehingga membuat usaha lebih kompetitif (Kaplinsky and Morris, 2001). Telaah terhadap rantai nilai komoditas unggulan di Misool Utara, yaitu kelapa, mengarahkan perlunya memodifikasi rantai nilai komoditas unggulan tersebut melalui diversivikasi produk olahan dan hilirisasi. Dengan diversifikasi produk olahan dan hilirisasi maka nilai tambah pada setiap mata rantai nilai dapat ditingkatkan. Adapun penelitian ini dilakukan bertujuan untuk mengetahui rantai nilai dan nilai strategis produk kelapa sebagai komoditas unggulan di Distrik Misool Utara.

\section{BAHAN DAN METODE}

Penelitian ini dilaksanakan selama bulan Oktober sampai Desember 2018. Lokasi pengambilan data yaitu pada Kampung Waigama, Salafen dan sekitarnya di Distrik Misool Utara Kabupaten Raja Ampat Provinsi Papua Barat. Pemilihan lokasi dilakukan secara purposive sampling, yaitu penentuan daerah sampel yang diambil secara sengaja berdasarkan pertimbangan tertentu, dimana pemilihan Distrik Misool Utara karena wilayah ini merupakan sentra perkebunan kelapa terbesar di Kabupaten Raja Ampat dan merupakan wilayah pengembangan komoditi kelapa dalam simpul marine-agro-wisata berdasarkan RTRW Kabupaten Raja Ampat Tahun 2011-2030 (Bappeda Kabupaten Raja Ampat, 2007).

Penelitian ini menggunakan metode dasar deskripsi kualitatatif. Metode deskripsi ini bertujuan untuk menggambarkan secara tepat sifat-sifat suatu individu, keadaan, gejala, atau kelompok tertentu, atau untuk menentukan frekuensi atau penyebaran suatu gejala. Teknik penelitian yang digunakan adalah metode survey, sebagai upaya untuk mengungkapkan jawaban melalui pertanyaan apa, bagaimana, berapa, 
bukan pertanyaan mengapa dengan menggunakan alat bantu kuesioner (Kountur, 2003; Silalahi, 2012 dalam Puspito dkk., 2016). Metode kualitatif dalam penelitian ini dilakukan dengan pendekatan pemahaman pedesaan dalam waktu singkat (Rapid Rural Appraisal /RRA). Sampel dalam penelitian di ditentukan dengan metode Snowball Sampling dengan Kepala Kampung Waigama sebagai informan kunci untuk merunut alur aliran produk komoditi kelapa mulai dari petani sampai pemasarannya.

Teknik pengumpulan data yang utama adalah wawancara semi struktural dengan para pemangku kepentingan, baik di tingkat kabupaten, distrik maupun kampung. Para pemangku kepentingan ditentukan melalui analisis pemangku kepentingan. Wawancara dilaksanakan secara perorangan maupun kelompok (focus group discussion/FGD). Teknik pengumpulan data lainnya adalah kajian pustaka, yaitu kajian terhadap laporan-laporan dan dokumen-dokumen lembaga pemerintah, LSM, dan lembaga penelitian, baik yang dipublikasikan maupun tidak dipublikasikan. Jenis data yang dikumpulkan dalam kajian ini digolongkan menjadi data primer dan data sekunder. Data primer diperoleh dengan cara wawancara terhadap para pemangku kepentingan dan pengamatan lapangan, sedangkan data sekunder diperoleh dari kajian pustaka terhadap laporan-laporan dan dokumendokumen lembaga Pemerintah seperti antara lain BPS, Bappeda, dan OPD terkait.

Data yang diperoleh dianalisis dengan metode kualitatif. Penelitian menggunakan pemetaan rantai nilai dan Analytical Hierarchy Process (AHP) untuk melakukan proses pengolahan dan analisis data. Struktur hierarki dalam metode AHP pada penelitian ini dibangun berdasarkan studi pustaka dari berbagai sumber tentang komoditi kelapa di Distrik Misool Utara.

Tabel 1. Sumbangan lapangan usaha terhadap produk domestik regional bruto (PDRB) Kabupaten Raja Ampat

\begin{tabular}{|c|c|c|c|c|c|c|}
\hline \multirow{2}{*}{ No } & \multirow{2}{*}{ Lapangan Usaha } & \multicolumn{4}{|c|}{ PDRB ADHK (Persentase) } & \multirow{2}{*}{$\begin{array}{l}\text { Rata-Rata } \\
\text { Per Tahur }\end{array}$} \\
\hline & & 2013 & 2014 & 2015 & 2016 & \\
\hline 1 & Pertanian, Kehutanan, dan Perikanan & 18,22 & 18,05 & 18,15 & 18,12 & 18,14 \\
\hline 2 & Pertambangan dan Penggalian & 33,96 & 33,33 & 31,38 & 29,68 & 32,09 \\
\hline 3 & Industri Pengolahan & 0,52 & 0,51 & 0,50 & 0,50 & 0,51 \\
\hline 4 & Pengadaan Listrik dan Gas & 5,99 & 6,11 & 6,08 & 6,03 & 6,05 \\
\hline 5 & $\begin{array}{l}\text { Pengadaan Air, Pengelolaan Sampah, } \\
\text { Limbah dan Daur Ulang }\end{array}$ & 9,73 & 9,63 & 9,91 & 10,14 & 9,85 \\
\hline 6 & Konstruksi & 4,61 & 5,30 & 5,97 & 6,65 & 5,63 \\
\hline 7 & $\begin{array}{l}\text { Perdagangan Besar dan Eceran; Reparasi } \\
\text { Mobil dan Sepeda Motor }\end{array}$ & 2,22 & 2,27 & 2,37 & 2,47 & 2,33 \\
\hline 8 & $\begin{array}{l}\text { Transportasi dan } \\
\text { Pergudangan }\end{array}$ & 0,33 & 0,34 & 0,36 & 0,37 & 0,35 \\
\hline 9 & $\begin{array}{l}\text { Penyediaan Akomodasi dan } \\
\text { Makan Minum }\end{array}$ & 0,31 & 0,32 & 0,33 & 0,34 & 0,33 \\
\hline 10 & Informasi dan Komunikasi & 0,15 & 0,15 & 0,15 & 0,15 & 0,15 \\
\hline 11 & Jasa Keuangan dan Asuransi & 0,30 & 0,31 & 0,32 & 0,33 & 0,31 \\
\hline 12 & Real Estate & 0,35 & 0,36 & 0,37 & 0,38 & 0,36 \\
\hline 13 & Jasa Perusahaan & 13,56 & 13,74 & 14,04 & 14,34 & 13,92 \\
\hline 14 & $\begin{array}{l}\text { Administrasi Pemerintahan, } \\
\text { Pertahanan dan Jaminan } \\
\text { Sosial Wajib }\end{array}$ & 8,82 & 8,68 & 9,12 & 9,54 & 9,04 \\
\hline 15 & Jasa Pendidikan & 0,66 & 0,64 & 0,65 & 0,66 & 0,65 \\
\hline 16 & $\begin{array}{l}\text { Jasa Kesehatan dan Kegiatan } \\
\text { Sosial }\end{array}$ & 0,17 & 0,16 & 0,16 & 0,16 & 0,16 \\
\hline 17 & Jasa lainnya & 0,10 & 0,11 & 0,12 & 0,13 & 0,12 \\
\hline
\end{tabular}

Sumber: Diolah dari BPS Kabupaten Raja Ampat, 2017

\section{HASIL DAN PEMBAHASAN}

\section{Gambaran Umum Usaha Perkebunan Kelapa}

Masyarakat di kawasan Distrik Misool Utara sebagian besar menggantungkan hidupnya pada sektor pertanian dan perkebunan. Hasil penelitian menunjukkan bahwa selama kurun waktu lima tahun terakhir yaitu antara tahun 2013-2017, sektor pertanian dan perkebunan merupakan sektor yang penting di Kabupaten Raja Ampat. Di bidang ketenagakerjaaan, 
sektor ini menjadi tulang punggung mata pencaharian masyarakat, dimana sekitar 77,07 persen penduduk Misool Utara bekerja di sektor tersebut. Perkembangan tenaga kerja sektor pertanian di Indonesia dari tahun ke tahun terus mengalami perubahan. Sektor pertanian merupakan sektor yang paling besar memberikan kontribusi tenaga kerja terhadap penyerapan tenaga kerja nasional. Besarnya kontribusi sektor pertanian terhadap perekonomian nasional tersebut menunjukkan bahwa sektor pertanian merupakan sektor yang masih bersifat padat karya (labour intensif) dibandingkan dengan padat modal (capital intensif). Hal tersebut terlihat dari kontribusi sektor pertanian terhadap penyerapan tenaga kerja nasional (Alexandi dan Marshafeni, 2013; Kuncoro, 2002).

Berdasarkan struktur ekonomi Kabupaten Raja Ampat, sektor pertanian bersama dengan sektor kehutanan dan perikanan merupakan penyumbang terbesar kedua dalam PDRB Kabupaten Raja Ampat setelah sektor pertambangan dan penggalian. Selama periode 2013-2016, kontribusi sektor pertanian dan perkebunan terhadap PDRB berfluktuasi yaitu sebesar $18,22 \%$ pada tahun 2013 menjadi $18,12 \%$ pada tahun 2016, dengan rata-rata secara keseluruhan adalah sebesar 18,14 persen per tahun (Tabel 1). Kedua indikator tersebut mengindikasikan pentingnya sektor pertanian dan perkebunan di Kabupaten Raja Ampat. Menurut Hidayat dan Darwin (2017) menyatakan bahwa pertumbuhan ekonomi merupakan salah satu acuan dalam melihat tingkat perekonomian dalam suatu wilayah. Semakin tinggi pertumbuhan ekonomi ini menggambarkan semakin tingginya tingkat investasi dalam suatu wilayah. Hasil penelitian ini hampir serupa dengan beberapa wilayah di Indonesia, seperti dalam penelitian Rudi et al. (2014); Rosyetti (2011) yang menyatakan sektor unggulan di sebagain wilayah Provinsi Riau yaitu Sektor Pertanian, Kehutanan, dan Perikanan.

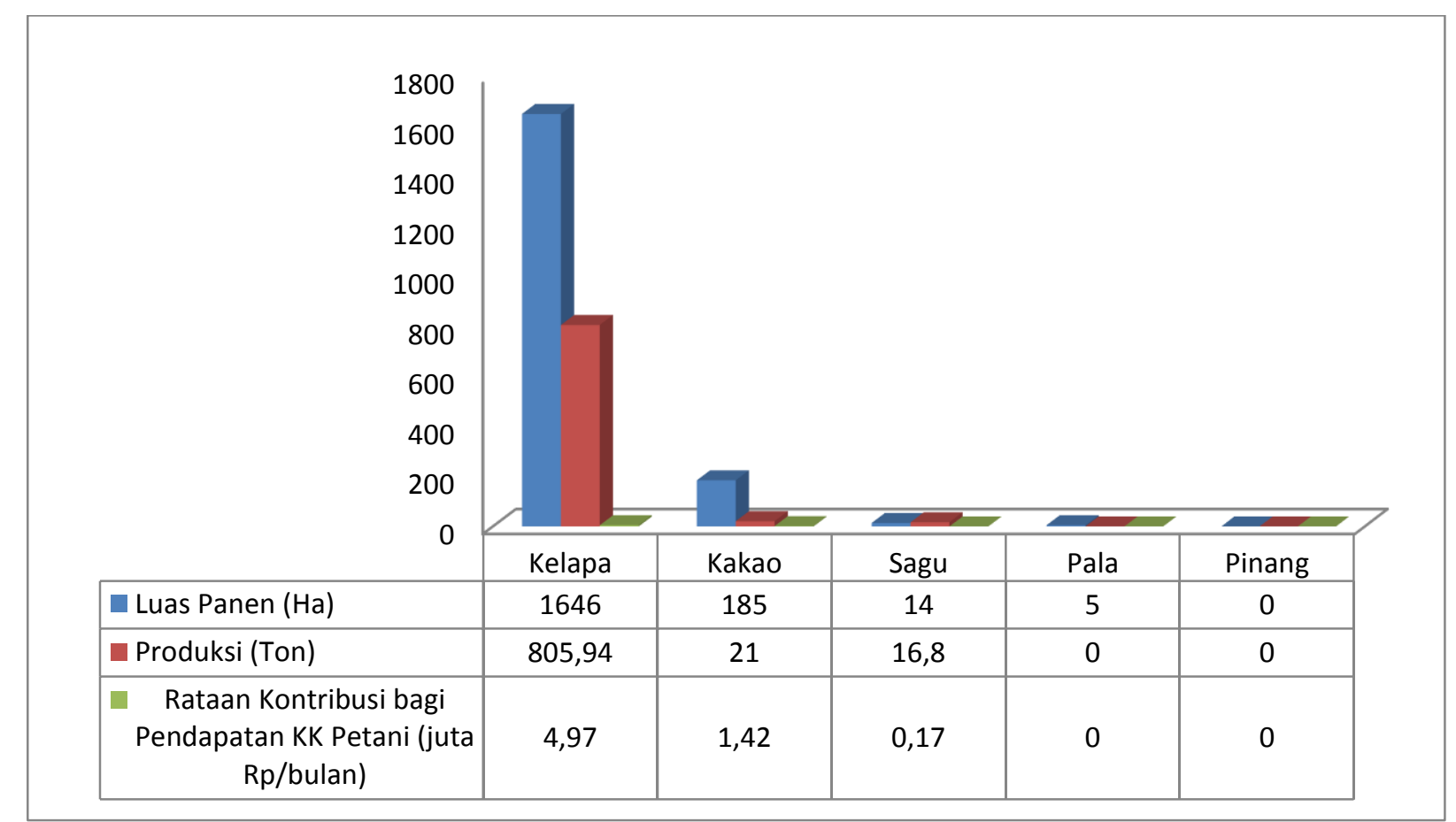

Keterangan: Diolah dari BPS Kabupaten Raja Ampat, 2017

Gambar 1. Luas areal, produksi, dan kontribusi bagi keluarga petani komoditas perkebunan di Distrik Misool Utara

Sub sektor perkebunan merupakan salah satu andalan utama dalam pendapatan rumah tangga, umumnya didominasi oleh perkebunan kelapa. Luas panen perkebunan kelapa rakyat di kawasan Distrik Misool Utara adalah 1646 hektar, atau sebesar 8,9 kali lipat luas panen kakao sebagai komoditi kedua terbesar pada Distrik Misool Utara. Dari areal tersebut produksinya mencapai 805,94 ton dengan rata-rata kontribusi bagi pendapatan keluarga petani sebesar 4,97 juta rupiah per bulan (Gambar 1). Bila dihitung maka produkstifitas kelapa yang dihasilkan petani Di Misool Utara adalah sebesar 0,49 ton per hektar.
Angka ini masih lebih rendah bila dibandingkan dengan hasil penelitian Patty (2011), dimana secara agregat, produktifitas kopra yang dihasilkan petani di Kabupaten Halmahera Utara adalah 0,731 ton kopra /ha dengan nilai produktifitas maksimum adalah 0,853 ton kopra /ha, dan produktifitas minimum sebesar 0,520 ton kopra/ha.

Hasil survey di lapangan menunjukkan masyarakat lebih banyak bekerja pada sektor perkebunan kelapa, dengan kopra merupakan hasil utama produksi perkebunan di kawasan ini. Produk utama perkebunan kelapa umumnya diolah menjadi 
kopra, dan dalam kondisi tertentu dijual dalam bentuk buah. Hasil wawancara di lapangan menunjukkan bahwa masyarakat di kawasan perdesaan Misool lebih memilih menjual kelapa dalam bentuk olahan kopra daripada buah karena hal tersebut sudah merupakan kebiasaan turun temurun, disamping karena faktor produksi dan ekonomi. Kelapa dipanen dan dijadikan kopra biasanya 3 bulan sekali dengan hasil rata-rata 14 ton. Pengelolaan kopra dilakukan dengan pengasapan yang bahan bakarnya berasal dari kayu, lama pengasapan dari kelapa sampai menjadi kopra memakan waktu selama 1 hari. Usaha pengolahan kopra dilakukan dengan tenaga kerja keluarga atau menyewa tenaga kerja di luar keluarga dimana pembagian hasil yang dilakuan adalah didasarkan pada hasil penjualan.

Hasil survey di lapangan menunjukkan terdapat persoalan yang dihadapi petani kelapa seperti terdapat lahan kelapa yang terserang hama namun berhasil diatasi, terdapat areal perkebunan kelapa yang sudah tua dan memerlukan peremajaan dengan pembukaan dan penanaman lahan perkebunan kelapa yang baru, serta petani sangat mengharapkan adanya industri pengolahan kopra di lokasi perdesaan Misool seperti di Waigama atau Salafen sebagaimana tertuang dalam Rencana Induk Pengembangan Kawasan Misool tahun 2016. Peran kelembagaan usaha tani dan agribisnis kelapa sangat diperlukan dalam pengembangan usaha perkebunan kelapa rakyat (Damanik, 2007).

\section{Rantai Nilai Komoditi Kelapa}

Usaha pertanian di Distrik Misool Utara yang menjadi sumber pendapatan penduduk adalah usahatani kelapa. Kelapa merupakan komoditas unggulan utama dari jenis usaha pertanian di Distrik Misool Utara. Kawasan produksi kelapa di utara Pulau Misool dan sekitarnya selain Distrik Misool Utara ada juga di Distrik Kepulauan Sembilan, dan Distrik Kofiau. Hasil penelitian menunjukkan bahwa teknik pemanenan kelapa di wilayah ini dilakukan petani dengan mengumpulkan kelapa yang cukup tua yang jatuh untuk diolah menjadi kopra. Umumnya petani mengumpulkan kelapa yang jatuh setiap tiga bulan sekali. Selama tiga bulan kelapa yang jatuh tidak dipungut oleh petani. Selama tiga bulan itu kebun kelapa di-sasi untuk menghindari pencurian buah kelapa yang telah jatuh. Seperti halnya beberapa daerah di Maluku dan Papua lainnya, Raja Ampat juga mengenal suatu bentuk kearifan lokal berupa sasi untuk pengelolaan sumberdaya alam. Model pengelolaan yang mempertimbangkan aspek kelestarian sumberdaya alam ini telah dikenal dan dipraktekkan dari generasi ke generasi (McLeod et al, 2009; Boli, 2014).

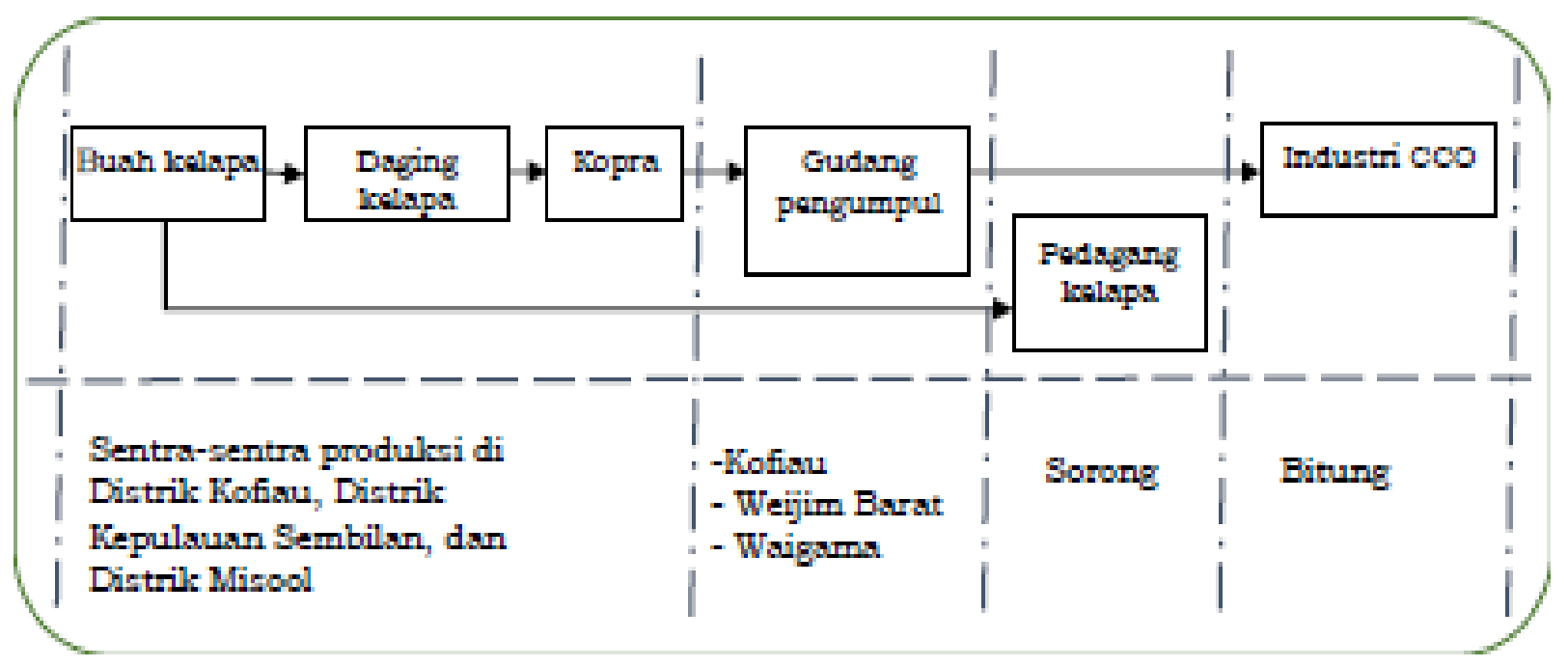

Gambar 2. Diagram alir (flow chart) rantai nilai komoditas kelapa di Misool Utara

Rantai nilai produk merupakan aktifitas yang berawal dari bahan mentah sampai dengan penanganan purna jual dan mencakup aktivitas yang terjadi karena hubungan dengan pemasok (supplier linkages) dan hubungan dengan konsumen (consumer linkages). Aktifitas ini merupakan kegiatan yang terpisah tapi saling ketergantungan. Analisis tantai nilai membantu untuk memahami posisi perusahaan atau produsen petani pada rantai nilai produk untuk meningkatkan keunggulan kompetitif (Wijk, 2009). Rantai nilai komoditas kelapa di Kawasan Misool Utara seperti dipetakan pada Gambar 2.
Peta rantai nilai kelapa pada Gambar 2 menunjukkan bahwa produksi, pengolahan dan pengumpulan kopra tersebar di hampir setiap distrik, dan semuanya dijual kepada pedagang kopra antar pulau yang menjual kopra ke Bitung. Kelapa segar semuanya dijual ke kota Sorong. Selain itu, peta rantai nilai kelapa menunjukkan bahwa hanya daging buah kelapa yang dimanfaatkan untuk diolah menjadi kopra, sedangkan sabut dan tempurung kelapa belum dimanfaatkan secara optimal, kecuali sebagai bahan bakar dalam pengolahan daging buah kelapa menjadi kopra melalui pengasapan. Hasil penelitian ini sejalan 
dengan Pisalemo dkk. (2018), yang menyatakan bahwa alur produk rantai nilai tepung kelapa dari petani masih berbentuk kelapa butir tanpa sabut, kemudian pemasok melakukan pendistribusian kepada perusahaan sebagai pengolah.

Kopra sebagai produk unggulan di Misool Utara sangat bergantung kepada pasar regional yang sangat dipengaruhi oleh harga kopra internasional dan harga produk-produk penghasil minyak nabati di pasar internasional. Hal tersebut menyebabkan usaha kopra rentan terhadap risiko pasar yang diakibatkan oleh fluktuasi produksi dan harga komoditas-komoditas penghasil minyak nabati di pasar internasional. Peningkatan produktivitas komoditas unggulan kelapa dapat ditingkatkan dengan memusatkan industri pengolahan kelapa menjadi kopra sehingga terjadi efisiensi. Selain itu, dapat dilakukan diversifikasi produk, dengan mengolah hasil sampingan, yaitu air kelapa, sabut, dan tempurung kelapa, serta membuat minyak kelapa. Hasil produksi olahan dapat dipasarkan secara lokal di kawasan penunjang, dan dipasarkan di pasar regional di Sorong dan ke luar Papua Barat.

\section{Nilai Strategis Produk Usaha Perkebunan Kelapa}

Produk unggulan di kawasan Misool Utara adalah produk dari usaha perkebunan kelapa beserta olahannya dan hasil tangkapan ikan. Hasil penelitian menunjukkan bahwa kelapa hasil kebun petani hanya dijual sebagai kelapa segar dan atau diolah menjadi kopra. Aktifitas menjual kelapa segar dibanding harus diolah menjadi kopra oleh petani kelapa pada dasarnya bertujuan untuk menciptakan dan meningkatkan nilai serta keuntungan kompetitif bagi usaha perkebunan mereka (Indriantoro dkk., 2012). Namun demikian petani kelapa di Misool Utara memiliki preferensi untuk mengolah kelapa menjadi kopra dibanding menjual buah kelapa segar. Hal tersebut disebabkan karena semua kelapa hasil panen dapat diolah menjadi kopra, tetapi hanya kelapa yang cukup tua dan belum bertunas yang bernilai untuk dijual sebagai kelapa segar. Namun demikian, rendahnya harga kopra menyebabkan turunnya minat petani untuk mengolah kelapa menjadi kopra, selain permintaan kopra juga menurun karena agen pedagang kopra menurunkan target pembelian dari petani. Hal tersebut menyebabkan menurunnya produksi kopra.

Berfluktuasinya harga kopra dengan kecenderungan harga yang menurun menimbulkan risiko pasar bagi petani. Pembentukan klaster yang ditujukan untuk memusatkan pengolahan kelapa dengan membuat pusat industri pengolahan kelapa memberikan kepastian harga karena petani di kawasan menjual kepada badan usaha yang dibentuk untuk mengolah kelapa menjadi berbagai produk. Badan usaha tersebut berfungsi meredam dan mengambil alih sebagian risiko pasar.

Strategi pemusatan pengolahan kelapa di pusat industri pengolahan kelapa di satu pihak akan menambah biaya transaksi di sisi petani, yaitu petani yang tinggal di luar lokasi pusat industri pengolahan, yakni petani-petani di Kampung Aduwei, Solal, Atkari, dan kampung-kampung di Distrik Kepulauan Sembilan, Distrik Kofiau dan Distrik Misool Timur. Petani tersebut akan mengeluarkan biaya transportasi dari kampungnya ke pusat industri pengolahan kelapa, yang besarnya bervariasi menurut jarak dari kampung ke pusat industri pengolahan kelapa di Kampung Salafen. Namun demikian pengeluaran tambahan tersebut dapat dikompensasi dengan dua cara. Pertama, karena petani tidak mengolah kelapa menjadi kopra secara langsung, maka petani tidak mengeluarkan biaya pengolahan kelapa menjadi kopra. Petani umumnya membayar biaya pengolahan kelapa menjadi kopra dengan cara bagi hasil, yaitu kopra hasil olahan dibagi dua antara pemilik kelapa dengan pekerja yang mengolah kelapa menjadi kopra. Dengan demikian biaya transportasi dapat dikompensasi dengan penurunan biaya pengolahan, sampai $50 \%$.

Cara lainnya adalah dengan membebankan biaya transportasi kelapa dari petani ke pusat industri pengolahan kelapa, yaitu kepada badan usaha yang menjalankan usaha pengolahan kelapa di pusat industri pengolahan kelapa, seperti BUMDES Bersama. Dengan pemusatan pengolahan kelapa di pusat industri pengolahan, volume usaha pengolahan meningkat sehingga dapat mencapai skala ekonomi sehingga memungkinkan investasi fasilitas pengolahan kelapa secara efisien disertai peningkatan kualitas produk kopra.

Pada saat ini produksi kopra di kawasan tersebar di kampung-kampung. Petani kemudian menjual kopra kepada agen pengumpul di Distrik Misool, Distri Kepulauan Sembilan, dan Distri Kofiau. Kopra yang dikumpulkan oleh para agen kemudian diangkut oleh perusahaan perdagangan kopra, umumnya ke Bitung, Sulawesi Utara. Pemusatan pengolahan kelapa menjadi kopra menjadikan transaksi dengan pedagang kopra menjadi lebih pendek. Pedagang kopra tidak perlu berkeliling kawasan dari satu kampung ke kampung lainnya untuk mengumpulkan kopra, dan hanya perlu bertransaksi dengan satu pihak, yaitu badan yang mengelola pengolahan kelapa. Hal tersebut menurunkan biaya transaksi di sisi pedagang kopa, sehingga dapat meningkatkan harga jual kopra kepada pedagang kopra. Pemusatan pengolahan kelapa menjadi kopra juga meningkatkan daya saing karna hanya satu produsen kopra di kawasan dengan volume produksi yang besar. Dengan demikian pusat industri pengolahan kelapa memiliki daya saing karena memiliki kekuatan penguasaan pasar. Dengan kekuatan penguasaan pasar, badan usaha pengelola industri pengolahan kelapa memiliki kekuatan menawar (bargaining power) yang lebih tinggi dan memiliki kemampuan untuk ikut menentukan harga (price maker).

Strategi pemusatan pengolahan kelapa di pusat industri pengolahan kelapa selain membagi risiko, 
meningkatkan daya saing karena dapat meningkatkan kualitas produk kopra dan penguasaan pasar, juga dapat meningkatkan nilai tambah dan menciptakan nilai produk. Nilai tambah produk ditingkatkan dengan cara merubah bentuk, waktu atau tempat. Dengan volume bahan baku yang mencapai skala ekonomi, badan usaha yang mengelola pengolahan kelapa memiliki peluang untuk dapat melakukan diversifikasi produk olahan kelapa. Selain kopra, daging buah kelapa dapat diolah menjadi berbagai produk lain, antara lain minyak goreng, kelapa bubuk, tepung kelapa, santan bubuk, virgin coconut oil (VCO), dan sabun. Selain meningkatkan nilai tambah, diversifikasi juga mengurangi risiko bisnis dengan tidak mengolah semua bahan baku kelapa menjadi satu jenis produk saja tetapi mengolahnya menjadi portofolio produk, sehingga menyebarkan risiko bisnis kepada produkproduk yang lain.

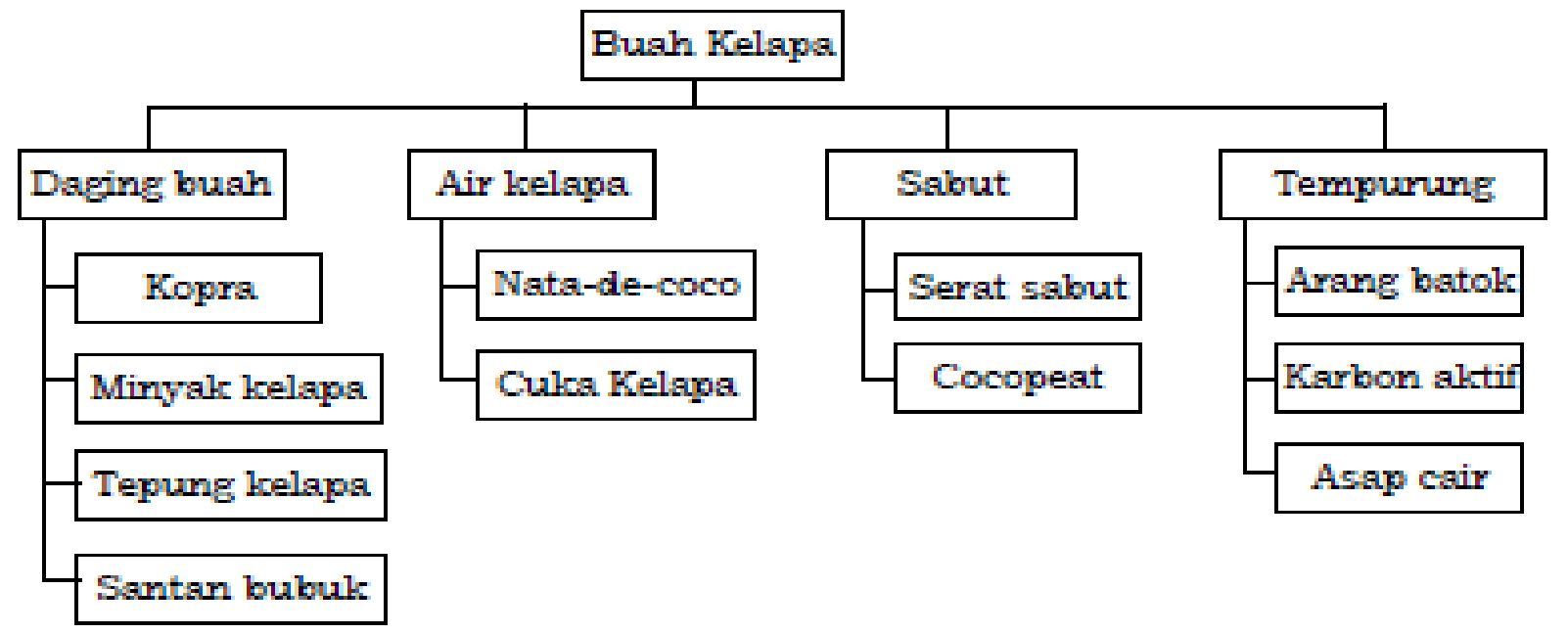

Gambar 3. Potensi diversifikasi dan penciptaan nilai produk olahan kelapa di kawasan Misool Utara

Penciptaan nilai produk dilakukan dengan mengolah bagian-bagian buah kelapa yang selama ini tidak dimanfaatkan, agar menjadi produk yang bernilai di pasaran. Selama ini hanya daging kelapa yang diolah menjadi kopra. Bagian-bagian lain dari buah kelapa, yaitu air kelapa, tempurung kelapa dan sabut kelapa dapat diolah menjadi produk yang memiliki nilai. Pemusatan pengolahan kelapa menghasilkan produk sampingan berupa air kelapa, tempurung kelapa dan sabut kelapa dalam jumlah yang mencapai skala ekonomi untuk diolah dengan skala industri yang membutuhkan investasi fasilitas pengolahan produkproduk yang menggunakan bahan baku tersebut. Air kelapa dapat diolah menjadi konsentrat air kelapa, nata-de-coco, dan cuka kelapa. Potensi diversifikasi dan penciptaan nilai produk olahan kelapa disajikan pada Gambar 3.

Luas areal pertanaman kelapa di wilayah Misool Utara (Distrik Misool, Kepulauan Sembilan, Kofiau, dan Misool Timur) mengalami kecenderungan penurunan. Hal tersebut disebabkan umumnya umur pertanaman kelapa sudah tua. Peremajaan kelapa yang dilakukan oleh Pemerintah Daerah belum mengimbangi berkurangnya luas areal tanaman akibat tanaman yang sudah tua. Produksi kelapa tidak mengalami peningkatan dalam lima tahun terakhir. Produktivitas perkebunan kelapa juga masih relatif rendah. Dengan produksi kelapa sebesar 8.300 ton per tahun, potensi produsi kopra di wilayah Misool Utara mencapai 2.000 ton per tahun. Sebelum harga kopra turun drastic dari Rp 6.000 per kilogram menjadi 2.500 per kilogram, produksi kopra di wilayah Misool Utara dapat mencapai sekitar 2.500 ton setahun. Turunnya harga menyebabkan turunnya minat petani untuk membuat kopra sehingga produksi kopra turun hingga sekitar 1.000 ton per tahun. Program peningkatan produksitivitas dan agribisnis kelapa diperkirakan dapat meningkatkan produksi kelapa sebesar $10 \%$ per tahun.

\section{SIMPULAN DAN REKOMENDASI}

Berdasarkan hasil penelitian dapat ditarik beberapa kesimpulan sebagai berikut : (1) luas panen perkebunan kelapa rakyat di kawasan Distrik Misool Utara adalah 1646 hektar, produksinya mencapai 805,94 ton dengan rata-rata kontribusi bagi pendapatan keluarga petani sebesar 4,97 juta rupiah per bulan. (2) rantai nilai kelapa produksi, pengolahan dan pengumpulan kopra tersebar semuanya dijual kepada pedagang kopra antar pulau yang menjual kopra ke Bitung dan (3) program peningkatan produksi dan produktivitas kelapa diperkirakan dapat meningkatkan produksi kelapa sebesar $10 \%$ per tahun.

Strategi pemusatan pengolahan kelapa di pusat industri pengolahan kelapa selain membagi risiko, meningkatkan daya saing karena dapat meningkatkan kualitas produk kopra dan penguasaan pasar, juga dapat meningkatkan nilai tambah dan menciptakan nilai produk. 


\section{DAFTAR PUSTAKA}

Alexandi, M. F., dan O. Marshafeni. 2013. Analisis Penyerapan Tenaga Kerja Sektor Pertanian dan Sektor Jasa Pasca Kebijakan Upah Minimum di Provinsi Banten. Jurnal Manajemen \& Agribisnis. 10(2): 74-78.

Bappeda Kabupaten Raja Ampat. 2007. Rencana Tata Ruang Wilayah Kabupaten Raja Ampat. Waisai: Pemerintah Daerah Kabupaten Raja Ampat.

Basmar, A. 2008. Arahan Pengembangan Kawasan Usaha Agro Terpadu Berbasis Komoditas Kelapa Di Kabupaten Lampung Barat. [Thesis]. Bogor: Institut Pertanian Bogor.

BPS Kabupaten Raja Ampat. 2017. Kabupaten Raja Ampat Dalam Angka Tahun 2017. Waisai: Badan Pusat Statistik Kabupaten Raja Ampat.

Boli, P. 2014. Pengelolaan Sumberdaya Karang Berbasis Integrasi Sasi Dengan Konservasi Perairan Modern Di Raja Ampat. [Thesis]. Bogor: Institut Pertanian Bogor.

Dahniar, A. Budiman, dan R. Wijaya. 2016. Analisis Rantai Nilai Industri Komoditas Kelapa Sawit Di Kalimantan Selatan. Prosiding Seminar Nasional Lahan Basah Tahun 2016. Jilid 1: 431-436.

Damanik, S. 2007. Strategi Pengembangan Agribisnis Kelapa (Cocos nucifera) untuk Meningkatkan Pendapatan Petani di Kabupaten Indragiri Hilir, Riau. Jurnal Perspektif. 6(2): 94-104.

Hidayat, M., dan R. Darwin. 2017. Analisis Sektor Unggulan Dalam Pengembangan Wilayah Kabupaten Kepulauan Meranti. Media Trend, Berkala Kajian Ekonomi dan Studi Pembangunan. 12(2): 156-167.

Indriantoro, F. W., E. G. Sa'id, dan P. Guritno. 2012. Rantai Nilai Produksi Minyak Sawit Berkelanjutan. Jurnal Manajemen \& Agribisnis. 9(2): 108-116.

Julianto, E. W., dan Darwanto. 2016. Analisis Rantai Nilai (Value Chain) Jagung Di Kecamatan
Toroh Kabupaten Grobogan. Jurnal Penelitian Ekonomi dan Bisnis. 1 (1): 1-15.

Kaplinsky, R., and M. Morris. 2001. A handbook for value chain research. Brighton, United Kingdom: Institute of Development Studies, University of Sussex.

Kuncoro, H. 2002. Upah Sistem Bagi Hasil dan Penyerapan Tenaga Kerja. Jurnal Ekonomi Pembangunan. 7(1): 45-54.

McLeod, E., B. Szuster, and R. Salm. 2009. Sasi and marine conservation in Raja Ampat, Indonesia. J. Coastal Management. 37(6): 656-676.

Patty, Z. 2011. Analisis Produktivitas Dan Nilai Tambah Kelapa Rakyat (Studi kasus di 3 kecamatan di Kabupaten Halmahera Utara). Jurnal Agroforestry. 6(2): 153-159.

Pisalemo, H., N. F. L. Waney, dan L. W. Th. Sondakh. 2018. Analisis Rantai Nilai Tepung Kelapa Pada PT. Tropica Cocoprima. Agri-Sosio Ekonomi Unsrat. 14(1): 169 - 174.

Puspito, D. P., Kusnandar, dan N. Setyowati. 2016. Analisis Rantai Nilai Ubi Kayu (Manihot esculeta crantz) Di Kabupaten Pati. Caraka Tani, Journal of Sustainable Agriculture. 31(2): 94-101.

Rosyetti. 2011. Analisis Sektor Potensial Kabupaten Kuantan Singingi. Jurnal Ekonomi. Vol. 19. No. 1.

Rudi, A.R., H. Zainal, dan K. S. Yani. 2014. Keterkaitan Sektor-Sektor Ekonomi Potensial di Provinsi Riau. J. MIMBAR. 30(1): 62-71.

Wardanu, A. P., dan M. Anhar. 2017. Strategi Pengembangan Agroindustri Kelapa Sebagai Upaya Percepatan Ekonomi Masyarakat Di Kabupaten Ketapang. Jurnal Industria. 3(1): $13-26$

Wijk, J. 2009. The Rise of Global Value Chains Value Chain Governance. Bogor: Class Lecture for Sustainable Business Development on MB-IPB. 